\title{
The Effect of the Brexit on Animal Welfare in the United Kingdom: A Case for Scepticism and Scrutiny
}

\author{
Oliver Wookey \\ LLB English and Spanish Law, MA Animal Law and Society
}

Reception: April 2018

Acceptance: April 2018

\begin{abstract}
The United Kingdom is scheduled to leave the European Union on the 29th March 2019. The political, legislative and ideological separation from the Union, its law and its institutions, draws into question the extent to which European laws will be maintained in the UK. As legislative protection for animal welfare in the UK is partly based off, has developed alongside, and is largely reliant on European Union legislation, the separation from the Union clearly requires consideration of how animal welfare protection will continue to be guaranteed in the UK, and how current standards can be upheld. While there is a case to be made for the Brexit being an opportunity to improve animal welfare standards domestically, I present a compelling argument for the need to address this optimism with scepticism and scrutiny. The reasoning of this is threefold. Firstly, that in spite of the positive history of animal law in the UK, the majority of animal welfare legislation in the UK is based on EU law, meaning that while its transposition is both necessary and possible, it will not be a simple task. Secondly, that in spite of clear ambition demonstrated by the Conservative Government, its position on certain animal welfare issues in recent years undermines its credibility for fulfilling such ambitious and uncharacteristic promises. Thirdly, that animal welfare concerns must be balanced with competing interests, but are often overlooked. Once having presented my case, I will consider the greater political context of the Brexit to suggest two possible reasons as to why such ambitious improvements to animal welfare have been pledged.
\end{abstract}

Keywords: Animal law, animal welfare, legislative protection of animals, European law, European Union, Brexit, conservative policy, Theresa May, Michael Gove

Resumen. El efecto del Brexit sobre el Bienestar Animal en el Reino Unido: un caso de escepticismo y control

La salida del Reino Unido de la Unión Europea está prevista para el 29 de marzo de 2019. La separación política, legislativa e ideológica de la Unión, su legislación y sus instituciones, pone en entredicho hasta qué punto se mantendrán las leyes europeas en el Reino Unido. Dado que la protección legislativa del bienestar de los animales en el Reino Unido, se basa 
en parte en la legislación de la Unión Europea, se ha desarrollado paralelamente a ella y depende en gran medida de ella, la separación de la Unión exige claramente que se considere cómo se seguirá garantizando la protección del bienestar de los animales en el Reino Unido y cómo se pueden mantener las normas actuales. Aunque hay que defender que el Brexit pueda ser una oportunidad para mejorar las normas de bienestar animal a nivel nacional, expongo un argumento de peso sobre la necesidad de abordar este optimismo con escepticismo y control. El planteamiento es triple. En primer lugar, que, a pesar de la positiva trayectoria de la legislación sobre bienestar animal en el Reino Unido, la mayor parte de la legislación británica se basa en la legislación de la UE, lo que significa que, si bien su transposición es necesaria y posible, no será una tarea sencilla. En segundo lugar, que, a pesar de la clara voluntad demostrada por el Gobierno conservador, su posición sobre determinadas cuestiones relativas al bienestar de los animales en los últimos años socava su credibilidad para cumplir unas promesas tan ambiciosas e inusuales. En tercer lugar, la preocupación por el bienestar de los animales debe conciliarse con otros intereses en conflicto, que a menudo se pasan por alto. Una vez que haya presentado mi argumentación, analizaré el contexto político general del Brexit para sugerir dos posibles razones por las que se han prometido mejoras tan ambiciosas del bienestar animal.

Palabras clave: Derecho animal, bienestar animal, protección legal de los animales, Derecho Europeo, Union Europea, Brexit, política conservadora, Theresa May, Michael Gove

\section{Introduction}

The United Kingdom is scheduled to leave the European Union on the $29^{\text {th }}$ March 2019. The political, legislative and ideological separation from the European Union, its law and its institutions, draws into question the extent to which European laws will be maintained in the UK. As legislative protection for animal welfare in the UK is partly based off, has developed alongside, and is largely reliant on European Union legislation, the separation from the Union clearly requires consideration of how animal welfare protection will continue to be guaranteed in the UK, and how current standards can be upheld. The EU's policy of harmonising legislation has often had the effect of constraining attempts by Member States to implement higher standards in their national systems. ${ }^{1}$ It is for this reason that Brexit not only provides an opportunity for the UK to enjoy greater scope to set its own legislative standards, but essentially that "Brexit presents many opportunities to improve the welfare of animals, both in the UK and overseas, in the coming years and decades". ${ }^{2}$ There is, indeed, a case to be made for the Brexit as an opportunity to develop improvements in animal welfare in the UK. In presenting this case in Part One, I will consider three key elements that support this point; firstly, the ambition demonstrated by leading ministers to not only maintain, but, where possible, improve, animal welfare standards following Brexit; secondly, the positive track record of animal welfare developments in the UK, both historically and in recent proposals, that give creditability to this ambition; and thirdly, the identification of areas of animal welfare that could plausibly be improved in national legislation, due to their particular resonance with the interests of the British public and their relevant to pressing issues currently under negotiation.

In spite of this evidence, however, it has also been acknowledged that "Brexit carries risks of dilution and erosion of hard-won animal welfare standards enshrined in EU law". ${ }^{3}$

\footnotetext{
1 "Brexit: Getting the best deal for animals", (Wildlife and Countryside Link, and the UK Centre for Animal Law, January 2018), p9

${ }^{2}$ ibid, p5

${ }^{3}$ ibid, p5 
After scrutinising the case for a possible improvement in animal welfare, I will in Part Two present a compelling argument to the effect that this positive outcome is by no means guaranteed, and that the promises made by leading ministers should be treated with the utmost scepticism and scrutiny. The reasoning of this is threefold. Firstly, that in spite of the positive history of animal law in the UK, the majority of animal welfare legislation in the UK is based on EU law, meaning that while its transposition is both necessary and possible, there is evidence to suggest that it will not be a simple task. Secondly, that in spite of clear ambition demonstrated by the Conservative Government, an examination of its position on certain animal welfare issues in recent years undermines its credibility for fulfilling such ambitious and uncharacteristic promises. Thirdly, that animal welfare concerns must be balanced with competing interests, but are often overlooked; I will provide evidence to the suggest that animal welfare interests may be compromised when negotiation trade agreements and subordinated by migration policy. Once having presented my case, I will use Part Three to consider the greater political context of the Brexit to suggest two possible reasons as to why such ambitious improvements to animal welfare have been pledged; firstly, that the optimism toward the future of animal welfare is an appeal to populism at a time of national political divide; and secondly, that the ambitiousness is part of the façade of a successful Brexit. It must be noted from the outset that in referring to the law and policy of the UK I will deal explicitly with the areas of animal law and policy that remain within the competence of the Government at Westminster in London; I will not broach the areas of animal law and policy that fall under the prerogative of the devolved powers of the UK.

\section{Part One: 'A Titanic Success'4}

As the arrangements for the withdrawal from the EU currently stand, the $29^{\text {th }}$ March 2019 marks the beginning of a 21-month transition period that will last until the $31^{\text {st }}$ December 2020. The purpose of this period is "to get everything in place and allow businesses and others to prepare for the moment when the new post-Brexit rules between the UK and the EU begin", 5 as well as to provide "more time for the details of the new relationship to be fully hammered out". ${ }^{6}$ A lengthening in the time for preparation should be beneficial to the UK as indeed, there is a plethora of issues to address in terms of readying the UK legal system for its detachment from EU law.

The first reason that we have to believe that Brexit could lead to an increased political focus on animal welfare is the concern and ambition displayed by certain influential members of the Government. Indeed, any pledges are, by themselves, insufficient to guarantee change, and animal welfare will not, of course, be found at the top of the agenda; promises to improve animal welfare are tempered with the need to balance welfare concerns with business and industry interests also. But, nevertheless, if we are to trust that the promises of those in power are not idle, the following statements do bode well for animal welfare in the future.

As Defra Secretary, Conservative MP and Leave ${ }^{7}$ enthusiast Michael Gove is in a position to be of key influence in animal welfare policy. It is therefore of great significance

\footnotetext{
${ }^{4}$ Foreign Secretary Boris Johnson promised that Brexit would be “a Titanic success”, see Elgot, Jessica, "Brexit will be titanic success, says Boris Johnson", (The Guardian, $3^{\text {rd }}$ November 2016), available at https://www.theguardian.com/politics/2016/nov/03/brexit-will-be-titanic-success-says-boris-johnson, accessed 16 April 2018

${ }^{5}$ Hunt, Alex, and Wheeler, Brian, "Brexit: All you need to know about the UK leaving the EU”, (BBC, 12 April 2018), available at http://www.bbc.co.uk/news/uk-politics-32810887 accessed 16 April 2018 ${ }^{6}$ ibid.

${ }^{7}$ The Leave coalition led the campaign in favour of leaving the European Union in the run up to the referendum. Its three most prominent figures were Defra Secretary Michael Gove, current Secretary of State for Foreign and Commonwealth Affairs and former Conservative Mayor of London Boris Johnson, and former leader of the United Kingdom Independence Party, Nigel Farage, all of whom played a pivotal role in winning the referendum by a majority of 52 to 48 votes.
} 
that he has, on multiple occasions, expressed his intentions to maintain our success as having "among the highest environmental and animal welfare standards of any nation on earth". ${ }^{8}$ Shortly after gaining his position as Defra Secretary, Gove set out his vision on the future of our natural environment in a speech entitled "The Unfrozen Moment - Delivering A Green Brexit". ${ }^{9}$ It was in this speech that he expressed his desire to see "higher standards across the board of animal welfare", ${ }^{10}$ impressing the need to "take action to tackle the trade in illegal ivory, improve scrutiny of what happens in our abattoirs, move on circus animals and examine the future of live animal exports" ${ }^{11}$ "Cruelty towards animals driven by man's worst exploitative instincts", ${ }^{12}$ he urged, "needs to be met with the full force of the law". ${ }^{13}$ In a later speech on farming, he once again demonstrated clear concern for welfare considerations in post-Brexit negotiations; insisting that it would be "foolish for us to lower animal welfare or environmental standards in trade deals", ${ }^{14}$ he envisions the creation of "a new gold-standard metric for food and farming quality", ${ }^{15}$ suggesting, specifically, increased investment in "sensor technology that can tell where, when and how livestock should be fed, housed and bred to maximise both yield and individual animal health and welfare". ${ }^{16}$ Most significantly, he insisted that "this government is committed to the very highest standards of animal welfare. As the Prime Minister has set out, we will make the United Kingdom a world leader in the care and protection of animals... this government will continue to promote and enhance animal welfare, both now and after we have left the EU". ${ }^{17}$

Prime Minister Theresa May has also set out her intentions to "maintain and enhance our animal welfare standards when we leave the EU". ${ }^{18}$ Addressing Parliament in 2017, she insisted "we should be proud that in the UK we have some of the highest animal welfare standards in the world - indeed, one of the highest scores for animal protection in the world". ${ }^{19}$ In light of this, she assured that "leaving the EU will not change that we are committed to maintaining and, where possible, improving standards of welfare in the UK, while ensuring of course that our industry is not put at a competitive disadvantage" ${ }^{20}$ Former Defra secretary Andrea Leadsom, in fact, somewhat reconciled the two potentially conflicting interests of maintaining adequate animal welfare standards `and negotiating profitable trade deals, preaching that our unique selling point, both nationally and internationally, should indeed be "the highest standards of animal welfare" ${ }^{21}$ Both ambitious

\footnotetext{
${ }^{8}$ Speech by Secretary of State Michael Gove, “Farming for the Next Generation” (5 January 2018) available at https://www.gov.uk/government/speeches/farming-for-the-next-generation, accessed 16 April 2018

${ }^{9}$ Speech by Secretary of State Michael Gove, “The Unfrozen Moment - Delivering a Green Brexit”, (21 July, 2017) available at https://www.gov.uk/government/speeches/the-unfrozen-moment-delivering-agreen-brexit, accessed 16 April 2018

10 ibid.

11 ibid.

12 ibid.

${ }^{13}$ supra 1, p13

${ }^{14}$ supra 9

15 ibid.

16 ibid.

${ }^{17}$ Written statement by Secretary of State Michael Gove, “Animal Welfare”, (23 November 2018) available at https://www.parliament.uk/business/publications/written-questions-answersstatements/written-statement/Commons/2017-11-23/HCWS267/, accessed 16 April 2018

18 “Animal Welfare: Theresa May Promises to Improve Standards”, (BBC, 22 November 2017) available at http://www.bbc.co.uk/news/uk-politics-42083552, accessed 16 April 2018

19 Becket, Adam, "Brexit poses a threat to animal welfare in the UK, a new report warns”, (Business Insider, 25 July 2017), available at http://uk.businessinsider.com/brexit-threatens-the-uk-high-animalwelfare-standards-2017-7, accessed 16 April 2016

${ }^{20}$ supra 1 , p23

${ }^{21}$ Case, Philip, "PM makes Brexit pledge on animal welfare”, (Farmers Weekly, 15 March 2017), available at http://www.fwi.co.uk/news/pm-makes-brexit-pledge-on-animal-welfare.htm, accessed 16 
and strategic, this would cater to the fact that "consumers in the UK, EU and beyond are increasingly looking for welfare-responsible products". ${ }^{22}$

This clear ambition is afforded credibility by the UK's positive track record in terms of promoting animal welfare standards irrespective of the influence of the EU, and its reputation as a leader in in animal welfare. The history of UK farm animal welfare policy exemplifies this, as "farm animal welfare has been an important issue for the UK for many years, including before the UK joined the EU". ${ }^{23}$ It was in 1822 that the UK passed its first piece of animal welfare legislation through Martin's Act, ${ }^{24}$ which sought to prevent excessive cruelty to cattle. Another key milestone was the 1965 investigation into the welfare of intensively farmed animals, resulting in the Brambell Report, ${ }^{25}$ which led to significant advances in UK farm animal welfare, and ultimately the establishment of the Agriculture Act $1967 .^{26}$ In fact, in the area of farming, there are three key examples where the UK has implemented higher regulatory standards than the baseline set by the EU. Firstly, "the UK prohibits the use of sow stalls throughout the sow's pregnancy, whereas the EU permits the use of stalls during the first four weeks of pregnancy". ${ }^{27}$ Secondly, UK law requires all calves to be given bedding, "while EU law only requires the provision of bedding for the first two weeks of life". ${ }^{28}$ Thirdly, the EU has "slightly higher stocking densities for broilers" than those permitted in most UK law. ${ }^{29}$

In 2006, the UK demonstrated clear consideration for animal welfare by enacting the Animal Welfare Act 2006, consolidating over 20 pieces of previous legislation, introducing a new welfare offence and creating a positive duty of care for pet owners, outlawing the neglecting of the basic needs of their animal, such as adequate nutrition and veterinary care. A 2010 review of the Animal Welfare Act 2006 concluded that, although higher standards could be met, "the Act provided a suitable framework for doing so and had already resulted in an improvement in animal welfare". ${ }^{30}$ In addition to this, "the Act had ultimately achieved its objectives of harmonising farm and companion animal welfare and consolidating and simplifying animal welfare legislation”. ${ }^{31}$ Perhaps most notably, the Act enshrines two key requirements: provision of the needs of animals, and the avoidance of unnecessary suffering, ${ }^{32}$ the latter of which being "rarely, if ever, found in European or other legislation these days", 33 and both of which allow considerable latitude when being interpreted by the courts due to their lack of definition. ${ }^{34}$

Animal Law in the UK has also seen recent proposals for legislative development by way of the Animal Welfare (Sentencing and Recognition of Sentience) Draft Bill, ${ }^{35}$ which introduces two key elements of animal welfare policy into national legislation. Firstly, it would "ensure that animals are defined in UK law as sentient beings". ${ }^{36}$ Aiming to "embed

\footnotetext{
April 2018

${ }^{22}$ Montague, Brendan, “Animal charities call on Theresa May's government to 'put words into action' on post-Brexit animal welfare”, (The Ecologist, 17 January 2018), available at https://theecologist.org/2018/jan/17/animal-charities-call-theresa-mays-government-put-words-actionpost-brexit-animal, accessed 16 April 2018

23 ibid. p23

${ }^{24}$ Martin's Act 1822

${ }^{25}$ supra 1, p23

26 ibid. p23

27 ibid. p23

${ }^{28}$ ibid. p23

${ }^{29}$ ibid. p23

${ }^{30}$ ibid. p7

${ }^{31}$ ibid. p7

32 ibid. p7

${ }^{33}$ ibid. p7

${ }^{34}$ ibid. p7

${ }^{35}$ Animal Welfare (Sentencing and Recognition of Sentience) Draft Bill

36 Policy Paper, “Draft Animal Welfare (Sentencing and Recognition of Sentience) Bill 2017”, Derecho Animal. Forum of Animal Law Studies, vol. 9/2 
the principle that animals are sentient beings, capable of feeling pain and pleasure, more clearly than ever before in domestic law"37 as part of its commitment "to raising animal welfare standards, and to ensuring animals will not lose any recognitions or protections once we leave the EU", 38 the Draft Bill "contains an obligation, directed towards government, to pay regard to the welfare needs of animals when formulating and implementing government policy". ${ }^{39}$ Not only would this replicate the obligations imposed by Article 13 of the Treaty on the Functioning of the European Union, to which the UK, along with all Member States, is currently bound, but it could potentially impose a stronger duty than that in Article 13, as not only could it apply in all policy areas (as opposed to a specific set, as in Article 13), but it "would not be limited to the caveat referring to 'religious rites, cultural traditions and regional heritage,", ${ }^{40}$

Secondly, it "increases the maximum penalty for animal welfare offences in the Animal Welfare Act 2006 from six months to five years' imprisonment" 41 in order to "give the courts the tools they need to deal with abhorrent acts of animal cruelty" ${ }^{42}$ In reaction to a spate of especially abhorrent acts of animal cruelty, this new legislative proposal will apply to "the most serious offences under the Act - causing unnecessary suffering, illegally mutilating an animal, illegally docking a dog's tail, illegal poisoning and encouraging an animal to fight”, 43 as well as to "convictions relating to attacks on service animals, including guide dogs, police and military dogs". ${ }^{44}$

In addition to the clear concern for animal welfare at domestic level, the UK plays a significant role on the global scale, and in spite of being separate from the European Union, the UK will continue to be an international player. Resuming its seat at the World Trade Organisation (WTO) for the first time in 44 years, not only will it be able to negotiate its own free trade agreements with consideration for animal welfare, but it will "continue to be at liberty to proactively lead and promote development and agreement of the highest possible animal welfare standards in relevant global bodies, such as the World Organisation for Animal Health (OIE)". ${ }^{45}$ An example of this is the opportunity in October 2018, when the UK will be hosting at the fourth of a set of high level Summits on Wildlife Trafficking. ${ }^{46}$ The UK can also promote standards as one of the largest shareholders in many International Financial Institutions, ensuring that "financial investment bodies have strong, well-enforced animal welfare and environmental policies", ${ }^{47}$ which are "key to incentivising improvements in agriculture systems globally". ${ }^{48}$

With manifest ambition on the part of the UK, it perhaps becomes clear why the failure to implement many possible improvements in animal welfare has often been attributed to the limitations imposed by the trade policies of the European Union. While acknowledging the many protections afforded to animals by the EU, Head of Public Affairs at RSPCA David Bowles argues that the EU has somewhat "handcuffed" the UK in limiting it from making

(Department for Environment, Food and Rural Affairs, 12 December 2017) available at https://www.gov.uk/government/publications/draft-animal-welfare-sentencing-and-recognition-ofsentience-bill-2017, accessed 16 April 2018

${ }^{37}$ ibid. p4

38 ibid. p4

${ }^{39}$ ibid. p4

${ }^{40}$ supra 1 , p11

${ }^{41}$ supra $36, \mathrm{p} 4$

42 ibid. p4

${ }^{43}$ ibid. p4

${ }^{44}$ ibid. p4

${ }^{45}$ supra 1 , p31

46 ibid. p31

47 ibid. p31

${ }^{48}$ ibid. p31 
certain improvements. ${ }^{49}$ One clear example is Article 2 of the animal experimentation directive $^{50}$ that, as a harmonising measure, "prohibits member states from introducing greater protection for animals than the directive requires" 51 in an area of animal exploitation on which $74 \%$ of the British public believe that more should be done to find alternatives. ${ }^{52}$ Brexit, therefore, offers an opportunity for these welfare concerns to be addressed, particularly as the specific elements of the Brexit negotiations pertain specifically to areas where improvements to animal welfare legislation could be made; firstly, where the British public has shown particular concern for a particular element of welfare, and secondly, where animal welfare could be taken into consideration for its relevance to policies that are currently under negotiation, such as controlling borders and access to fisheries.

First of all, the development of national laws following Brexit offers an opportunity to legislate in areas where the majority of the British public has demonstrated particular concern for certain practices that threaten animal welfare. ${ }^{53}$ Three key cases of welfare concerns clearly demonstrate this. The first of these is the existing fur trade ban of the EU, which only prohibits fur made from cat, dog and seal; a report by The Ecologist holds than an overwhelming $90 \%$ of the British population wants a total ban on fur products. ${ }^{54}$ The second is the highly contested sale of foie-gras; the UK has been unable to ban its import due to the EU free movement of goods principle, despite the fact that the UK has already banned domestic production and 63\% of the UK public support a ban on animal welfare grounds. ${ }^{55}$ The third opportunity would be to improve the welfare of farmed animals by providing the UK with a chance to redesign its agricultural policy. There are, in fact, two good reasons to be optimistic about this possible improvement. The first reason is that key figure George Eustace, Minister for Agriculture, committed to "place greater emphasis on animal welfare in the design of agriculture policy" ${ }^{56}$ The second reason is that British farmers have often attributed the lack of improvement in farm animal welfare to the limitations imposed by EU policy; according to farmers, the EU principles of free movement of goods has meant that "investment in and production from higher welfare systems could be undermined by imports of products coming from countries with lower standards of animal welfare" ${ }^{57}$ Freedom from EU principles means that a redesign would be possible. The UK currently pays $£ 3$ billion annually to support farmers, $80 \%$ of which is based on farm size, with $20 \%$ given for environmental benefits. A rethink of the public support for agriculture could both enable and reward better animal welfare and environmental standards; ${ }^{58}$ this could be achieved as follows: "the Government should first define what kind of food and farming system we want - what we want it to achieve - and then establish how public funding can help to move the UK towards that desired system". ${ }^{59}$

Secondly, an opportunity presents itself in the development of national laws relating to policy areas that are currently under consideration, and where animal welfare concerns could be taken into consideration. The highly contentious question of how to manage British borders following Brexit presents an excellent opportunity to "close loopholes in the Pet

49 "Forty animal charities call for Government to put words into action on Post-Brexit animal welfare", (Wildlife and Countryside Link, 16 January 2018), available at https://www.wcl.org.uk/forty-animalcharities-call-for-government-to-put-words-into-action-on-post-brexit-animal-welfare.asp, accessed 16 April 2018

${ }^{50}$ supra 1 , p41

51 ibid, p41

52 ibid, p41

${ }^{53}$ Montague, Brendan, supra 22

54 ibid.

55 ibid.

${ }^{56}$ supra 1, p27

${ }^{57}$ supra 49

${ }^{58}$ supra 1, p27

${ }^{59}$ supra 49 
Travel Scheme," which has been criticised for facilitating the "cruel trade in poorly bred pups from Central and Eastern European puppy-farms". ${ }^{60}$ Unnecessary suffering could be reduced by both improving border checks and reintroducing blood-testing requirements. Secondly, reconsidering border standards, the UK will be in a better position to proactively promote higher levels of protection for threatened species affected by trade, such as a good opportunity to introduce a comprehensive ban on domestic trade and import and export of ivory. Overall a stricter 'positive list approach' could be beneficial, whereby “anything on the list can come in, anything not can't'. ${ }^{6}$

Discussions on the access agreements to British and European fisheries offer an opportunity for the UK to take a lead in this policy area where, in terms of regulating fishing laws so as to account for welfare concerns due to fishing practices, the EU has no laws. ${ }^{62}$ Wild-caught fish currently suffer during capture, landing and processing, experiencing fear, pain and distress, as they are; pursued to exhaustion by nets, crushed under the weight of other fish in trawl nets, suffer decompression effects when raised from deep water, caught on hooks. ${ }^{63}$ With scientific evidence demonstrating the need for welfare concerns of fish to be addressed, ${ }^{64}$ Brexit "provides a convenient opportunity for the Government to make detailed, species-specific regulations to safeguard the welfare of farmed fish and other farmed animals in relation to their husbandry, transportation and slaughter". ${ }^{65}$

\section{Part Two: The Case for Scepticism and Scrutiny}

Clearly, when considering the arguments and evidence presented above on the whole, the Brexit can, indeed, be presented as an excellent opportunity to increase protection for animal welfare in national legislation. The UK has, and could continue to be, a global leader in animal welfare; the ambition demonstrated by leading politicians provides reason to believe that this is possible, especially as there are many improvements to be made beyond EU standards that not only are proven to be concerns of the British public, but are relevant to policy issues that are currently being negotiated. However, this optimism must be tempered by evidence suggesting that these possible improvements are by no means guaranteed. I will proceed to present three reasons as to why the case for Brexit as an opportunity for improvement should be met with scepticism and scrutiny. The first reason is that, in spite of the positive history of animal law in the UK, the majority of animal welfare legislation in the UK is based on EU law; it is for this reason that total transposition of EU law is key to maintaining current protections, however there is evidence to suggest that this may not be simple. Secondly, that in spite of clear ambition demonstrated by the Conservative Government, an examination of its position on certain animal welfare issues in recent years undermines their credibility for fulfilling such ambitious and uncharacteristic promises. Thirdly, that animal welfare concerns must be balanced with competing interests, but are often overlooked; I will provide evidence that suggests that animal welfare interests may be compromised during the Brexit also.

\section{ii.i The Inherent Difficulties of Transposing EU Law}

The report 'Brexit: getting the best deal for animals" emphasises the critical importance that "all protection measures currently afforded to animals under EU law are transposed into UK law". ${ }^{66}$ The report, which has been produced by a conglomerate of animal protection

\footnotetext{
${ }^{60}$ ibid.

61 ibid.

${ }^{62}$ supra 1, p20

63 ibid, p20

64 ibid, p20

65 ibid, p29

${ }^{66}$ ibid, p7 
groups, ${ }^{67}$ also provides clear reasoning as to why this is so crucial. After outlining three key reasons as to why transposition is so important, I will demonstrate that the identification of the difficulties inherent in the transposition, as well as a critical analysis of the Government's European Union (Withdrawal) Bill, give reason to believe that the total transposition recommended by animal protection organisations may, in fact, be problematic.

Firstly, a total transposition of EU legislation is necessary due to the nature of EU secondary legislation. EU secondary legislation is primarily composed of regulations and directives, which act in different ways; "the key difference between them is that regulations are directly effective as part of the law of all EU states, without a need for national implementing measures, while directives set out the results to be achieved and require EU states to adopt national implementing measures for achieving those results" ${ }^{68}$ In the case of directives, there will likely already be UK legislation implementing these laws, but it may need to be adapted due to the reference made to European institutions that will no longer be relevant. However EU legislation in the form of a regulation may not have corresponding national legislation, meaning that any protections conferred by regulation will likely not be guaranteed without their adequate transposition.

This difficulty with ensuring the adequate reflection of secondary legislation in domestic systems will be exacerbated further by the discontinued influence of the EU's enforcement mechanisms. The European Court of Justice (ECJ) - a fundamental European institution "tasked to ensure that member states abide by EU regulations and directives"69 will no longer have influence over the UK. Therefore the ECJ will no longer be able to ensure that protections conferred by Directives are adequately transposed into domestic legislation. This is especially important for animal welfare standards, as "interpretations by the ECJ are, in some cases, wider than the constructions of UK law". ${ }^{70}$ An example of this is the ECJ's expansion of the term 'deliberate' in relation to the Habitats Directive that, according to a review carried out by the Law Commission, the UK failed to adequately incorporate. ${ }^{71}$ It is also essential the guarantee current standards that the UK prioritises the replacement or strengthening monitoring bodies. ${ }^{72}$ In terms of farming, for example, the EU has "a long history of providing scientific information on farm animal welfare", ${ }^{73}$ which has been used to inform legislation through the European Food Safety Authority (EFSA), the Scientific Committee on Animal Health and Welfare (SCAHAW), and the Scientific Veterinary Committee (SVC). ${ }^{74}$ The only similar independent body in the UK is the Farm Animal Welfare Council (FAWC), and it is therefore crucial that funding for this body be secured as a priority when planning funding post-Brexit if, indeed, the crucial monitory role is to be fulfilled.

Secondly, transposition is so crucial because of the huge role played by European legislation in national animal welfare protection. As it currently stands, an incredible $80 \%$ of legislation for animal welfare in the UK comes from the EU. ${ }^{75}$ In terms of farming, "EU directives lay down minimum standards for the protection of animals bred or kept for farming purposes", ${ }^{76}$ with species-specific directives covering pigs, calves, broiler chickens and

\footnotetext{
${ }^{67}$ Brought together by the Wildlife and Countryside Link and the UK Centre for Animal Law, the proposals and recommendations of the report have been developed and supported by 41 other animal organisations

${ }^{68}$ supra 1 , p9

69 ibid, p13

${ }^{70}$ ibid, p13

${ }^{71}$ ibid, p14

72 supra 49

${ }^{73}$ ibid.

74 ibid.

75 “Brexit”, (RSPCA Political Animal, 2018) available at http://politicalanimal.org.uk/england/brexit/, accessed 16 April 2018

${ }^{76}$ supra 1 , p23
} 
laying hens. ${ }^{77}$ For the welfare of wildlife the Habitats Directive ${ }^{78}$ "lists over 1,000 animal and plant species and 200 habitat types in its annexes, each protected in various ways", ${ }^{79}$ in addition to specifically annexing certain species that can enjoy protections against exploitation and taking from the wild. ${ }^{80}$ While EU legislation on companion animals could be improved, it still regulates various areas of relevance to health and welfare of animals including dogs, cats and equines, such as "commercial pet movements; the welfare of animals during transport; and, the sale and import/export of cat and dog fur". ${ }^{81}$ The EU Directive on the protection of animals used for scientific purposes ${ }^{82}$ contains many animal welfare measures, such as ensuring the legality of experiments by imposing on member states the requirement of "two levels of authorisation: one for the breeder, supplier or user (establishment); and one for each project". ${ }^{83}$ The animal welfare legislation of the EU is clearly fundamental to national animal law protection.

Thirdly, the importance of a total transposition is due to a certain clause included in the Withdrawal Bill. The Henry VIII clause will play a key role in amending legislation once separate from the Union by "enabling Ministers to make statutory instruments which can amend even primary legislation". ${ }^{44}$ The point of this is to ensure that the UK is ready for Brexit when at the end of the transition period, allowing that, where necessary, legislative amendments can be made instantly by the bypassing of Parliament. The danger here is that "there will, however, inevitably be choices open to Ministers about how they replace legislative references to EU mechanisms and institutions", 85 and without the scrutiny of Parliament, and, essentially, the ability to legislate free of scrutiny, that animal welfare will not be prioritised when faced with competing interests.

It is crucial, therefore, that European legislation is transposed into national law before exiting the European Union. And, indeed, the UK has already attempted to organise this transition by introducing the European Union (Withdrawal) Bill to Parliament; ${ }^{86}$ so as to end the primacy of EU law in the UK and to ensure a smooth transition on exit day, this bill will "incorporate all EU legislation into UK law in one lump, after which the government will decide over a period of time which parts to keep, change or remove". ${ }^{87}$ Indeed, this would "avoid a black hole in our statute book" ${ }^{88}$ as well as "aid trade negotiations with the EU because the UK will already meet all of its product standards". ${ }^{89}$ However there are two key issues with this that, in my opinion, shed doubt on the success of this task of transposition and, ultimately, threaten the maintenance of animal welfare protection in national legislation.

Firstly, there is a clear practical difficulty in this task. While a total transposition of European law into domestic law does seem ideal in this respect, it is not devoid of shortcomings; a White Paper compiled by the UK government entitled 'Legislating for the United Kingdom's withdrawal from the European Union' ${ }^{90}$ has stated that "swathes of UK

\footnotetext{
77 ibid, p23

${ }^{78}$ Council Directive 92/43/EEC of 21 May 1992 on the conservation of natural habitats and of wild fauna and flora, Official Journal L 206 of

22.7.1992 p 7. Available at: http://eur-lex.europa.eu/legal-content/EN/TXT/?uri=CELEX:31992L0043

${ }^{79}$ supra 1 , p14

${ }^{80}$ ibid, p14

81 ibid, p33

82 ibid, p41

${ }^{83}$ ibid, p42

${ }^{84}$ ibid, p9

${ }^{85}$ ibid, p9

${ }^{86}$ Hunt, Alex, and Wheeler, Brian, supra 5

87 ibid.

88 "EU Withdrawal Bill: A guide to the Brexit repeal legislation", (BBC, 13 November 2017), available at http://www.bbc.co.uk/news/uk-politics-39266723, accessed 16 April 2018

89 ibid.

90 Policy Paper, “Legislating for the United Kingdom's withdrawal from the European Union”, (Department for Exiting the European Union, 15 ${ }^{\text {th }}$ May 2017), available at
} 
law 'will no longer work' on exit”, ${ }^{91}$ as much UK legislation will require adaptation due to the reference it makes to EU institutions..$^{92}$ In essence of this, it is also crucial that laws are amended, where necessary, to achieve the same objective. The difficulty of the task is, however, exacerbated by the sheer enormity of EU law; known as the Acquis Communautaire, ${ }^{93}$ it dates back to 1958 and, in 2010, was estimated to consist of around 80,000 items, ${ }^{94}$ including treaties, regulations, directives and rulings from the European Court of Justice. ${ }^{95}$ Amending law that no longer works on exit will therefore be a monumental task, and given the clear time limit under which the UK is working, there are foreseeable problems, such as the eventual need to resort to the Henry VIII clause.

The second reason for doubting the success of guaranteeing EU animal law in domestic legislation is the fact that there have already been two major issues with the replication of Article 13 of the TFEU. Indeed, I earlier praised the efforts of the Government to propose the Animal Welfare (Sentencing and Recognition of Sentience) Draft Bill as a means of conferring the duty enshrined in Article 13 that requires Ministers "to 'have regard' to the welfare requirements of animals when formulating and implementing policies". ${ }^{96}$ However in reality, under the façade of this bill lie two major indications that the transposition of this fundamental piece of animal welfare legislation may be flawed.

The first indication to suggest this is that originally, the sentience clause was not included in the Withdrawal Bill, and when an amendment to include the sentience clause was recommended by Green Party MP Caroline Lucas it was immediately rejected. Following this, she criticised the rejection of her suggested amendment as "absurd", ${ }^{97}$ as ditching the provision would be "such a backwards step" ${ }^{98}$ She also emphasised the importance of including the animal sentience protocol as "an instruction to future governments when creating legislation". ${ }^{99}$ The ordeal quickly became "the most read political story of 2017", ${ }^{100}$ rapidly spreading online and "being shared more than 500,000 times on social media". ${ }^{101}$ Only after heavy criticism on social media and campaigns in favour of the amendment by 38 Degrees, Compassion in World Farming and other groups, ${ }^{102}$ did Gove respond, justifying the decision to omit the provision by dismissing the Withdrawal Bill being the place to address the issue. ${ }^{103} \mathrm{He}$ also criticised the provision for having an unclear effect, and for having "failed to prevent practices across the EU which are cruel and painful to animals", ${ }^{104}$ and finally promised "to make any necessary changes to UK law to recognise that animals can feel pain". ${ }^{105}$ While Gove used this as an opportunity to criticise "the way that social

\footnotetext{
https://www.gov.uk/government/publications/the-repeal-bill-white-paper/legislating-for-the-unitedkingdoms-withdrawal-from-the-european-union, accessed 16 April 2018

${ }^{91}$ supra 1 , p9

92 ibid, p9

${ }^{93}$ supra 88

94 ibid.

95 ibid.

${ }^{96}$ supra 1, p11

${ }^{97}$ Mason, Rowena, “Gove says UK will specifically recognise animal sentience”, (The Guardian, 23

November 2017), available at https:/www.theguardian.com/world/2017/nov/23/uk-law-willspecifically-recognise-animal-sentience-michael-gove, accessed 16 April 2018

98 ibid.

${ }^{99}$ ibid.

${ }^{100}$ Becket, Adam, “Theresa May insisted on including fox hunting pledge in Conservative manifesto”, (Business Insider, 27 Nov 2017), available at http://uk.businessinsider.com/theresa-may-insisted-onincluding-fox-hunting-pledge-in-conservative-manifesto-2017-11, accessed 16 April 2018

101 ibid.

${ }^{102}$ Mason, Rowena, supra 87

103 ibid.

104 ibid.

105 ibid.
} 
media 'corrupts and distorts' political stories", ${ }^{106}$ blaming it for aiding "the spread of 'fake news "', ${ }^{107}$ it seems that it was only by result of public outrage and media backlash that the sentience clause was given attention. As a result, on the $12^{\text {th }}$ December 2017 Parliament was presented with the Animal Welfare (Sentencing and Recognition of Sentience) Draft Bill, which ensured that "animals are defined in UK law as sentient beings". ${ }^{108}$

The second indication is the criticism contained in the Pre Legislative Scrutiny of the Draft Animal Welfare Bill report published by the Defra Committee. ${ }^{109}$ While recognising that the Bill deals with "important and worthwhile" concepts, ${ }^{110}$ the draft was criticised overall for "being presented to the public - and Parliament - in a far from finished state". ${ }^{111}$ This is based on the fact that "many of the key concepts of the Bill remain undefined", ${ }^{112}$ and "the lack of a formal regulatory impact assessment". Relating specifically to the element of sentience, the Committee was worried that "the vagueness and ambiguity of the purpose and meaning of Clause $1 \ldots$ will impede and delay the introduction of this measure" ${ }^{113}$ It recommended, therefore, that Clause 1 be separated entirely and be introduced in a separate piece of legislation. ${ }^{114}$ There has been no further development since.

\section{ii.ii Recent Conservative Animal Welfare Policy}

Given the immense importance of transposition for ensuring that animal protection derived from EU law is guaranteed following Brexit, it is extremely disappointing to see that there is already evidence to suggest that the already problematic process of transposition has been worsened by a failure of the Government to adequately deal with the key protections encapsulated by Article 13 TFEU. Unfortunately, this only provides further evidence for the second reason for which I believe we should not be too hasty to place faith in the pledges of the leading Ministers. While these pledges are, in themselves, promising, when contextualised within Conservative history, they are revealed to be uncharacteristic. There are three major examples of where the Conservative party has shown a clear lack of concern for animal welfare; its failure to implement the Circus Animals Draft Bill; its multiple attempts to repeal the fox hunting ban; and its attempt to repeal animal welfare codes. If these past actions are any indication of how seriously Conservative rhetoric can be taken, then it shows we must have caution in trusting it, and hold ministers accountable with rigorous scrutiny.

The Draft Wild Animals in Circuses Bill ${ }^{115}$ was suggested by the Labour Party in 2010 in response to the suffering of wild animals used in travelling circuses due to the failure of the licensing scheme to meet welfare requirements. Developed under the Coalition Government, the draft bill set out a total ban on the use of wild animals in travelling circuses, as well as conferred extensive powers of investigation and enforcement on authorities. ${ }^{116}$ The Conservative Government has since publicised its intention to pass the bill "as soon as the legislative programme [allowed]", ${ }^{117}$ however eight years after its creation, lack of

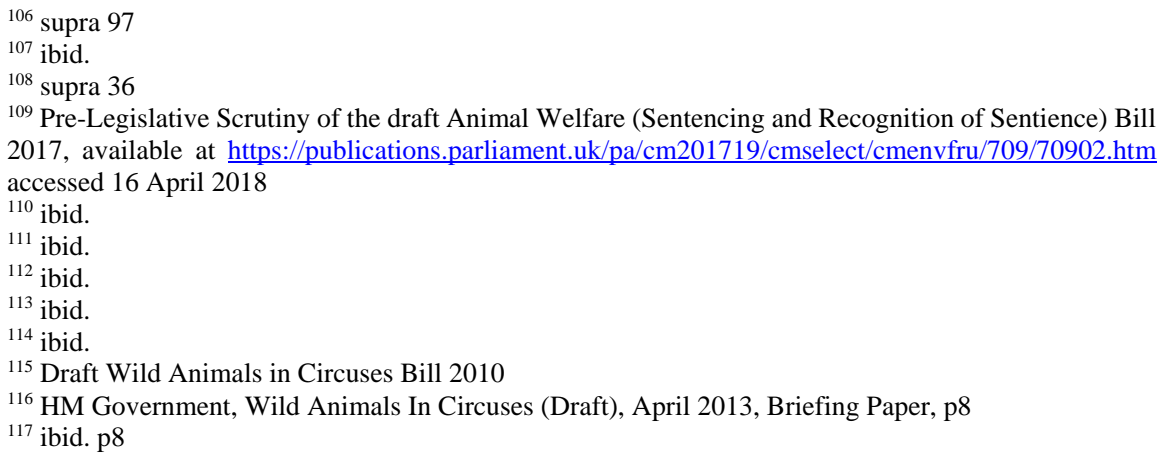


prioritisation from the Conservatives has left wild animals in circuses at the mercy of the licensing scheme.

A "key moment in the history of animal protection legislation", 118 the enactment of the Hunting Act $2004^{119}$ effectively banned fox hunting by prohibiting the chasing of wild mammals with dogs in England and Wales. ${ }^{120}$ However it has been faced with heavy pressure from the hunting lobby and the Conservative leadership, opening it to possible repeal and threatening the animal welfare protections it currently ensures. The fact that it has been praised by the League Against Cruel Sports as "the most successful piece of animal welfare legislation in history", ${ }^{121}$ and received the support of " $80 \%$ of the British public"122 has not stopped both former and current Conservative Prime Ministers David Cameron and Theresa May from attempting to repeal it. Cameron claimed that "the Hunting Act [had] done nothing for animal welfare", ${ }^{123}$ and during his campaign promised that upon winning the election he would "hold a parliamentary vote" for its repeal. ${ }^{124}$ This promise was, however, revoked, when the Scottish National Party claimed that it would vote against this "shabby attempt to repeal a successful piece of animal welfare legislation by the back door". ${ }^{125}$ Theresa May also made a pledge to hold a free vote on repealing the ban before the 2017 General Election, ${ }^{126}$ stating that she has "always supported fox hunting", ${ }^{127}$ as "other forms of dealing with foxes can be cruel". ${ }^{128}$ If it is her true belief that control of wild animal populations is best achieved by the chasing, catching, and tearing apart of a creature by a pack of dogs accompanied by uniformed hunters on horseback, then she is in no credible position to comment on animal welfare concerns at all.

As part of a deregulatory agenda, former Conservative environment secretary Liz Truss sought to "scrap the statutory codes on farm animal welfare and move to 'industry-led' guidance", ${ }^{129}$ repealing an array of official guidelines "starting with a move to put the code on chicken-farming into the hands of the poultry industry". ${ }^{130}$ In defence of the change, a Defra spokesperson made the assurance that "no changes are being made to farm animal welfare legislation or the strict enforcement and penalties that apply", ${ }^{131}$ however this statement has not been enough to silence the concerns of organisations that fear a possible

118 "Strengthen the Hunting Act”, (League Against Cruel Sports), available at https://www.league.org.uk/hunting-act, accessed 16 April 2018

${ }^{119}$ Hunting Act 2004

${ }^{120}$ supra 118

121 Stone, Jon. "David Cameron says he wants to repeal the fox hunting bill”, (The Independent, 6 March 2015) http://www.independent.co.uk/news/uk/politics/david-cameron-says-he-wants-to-repealthe-fox-hunting-ban-10091571.html accessed 16 April 2018

122 ibid.

123 ibid.

124 ibid.

125 Mason, Rowena. “Government shelves foxhunting vote after SNP opposition”, (The Guardian, 14 July 2015)

https://www.theguardian.com/uk-news/2015/jul/14/foxhunting-vote-shelved-by-tories-in-face-of-snpopposition accessed 16 April 2016

${ }^{126}$ Osbourne, Samuel. “Teresa May announces she wants to bring back fox hunting”, (The Independent, 9 May 2017) http://www.independent.co.uk/news/uk/politics/theresa-may-fox-hunting-bring-back-banrepealconservative- tories-general-election-rural-vote-a7726506.html accessed 16 April 2018

${ }^{127}$ Stone, Jon, “Theresa May says she supports fox hunting because other ways of killing foxes are 'cruel'”, (The Independent, 16 May 2017), available at https://www.independent.co.uk/news/uk/politics/theresa-may-fox-hunting-conservatives-tories-banbring-back-repeal-hunting-act-general-election-2017-a7737881.html, accessed 16 April 2018 128 ibid.

${ }^{129}$ Mason, Rowena, “Government Planning to Repeal Animal Welfare Codes” (The Guardian, 25 March 2016) available at https://www.theguardian.com/lifeandstyle/2016/mar/25/government-planning-torepeal-animal-welfare-codes, accessed 16 April 2018

130 ibid.

131 ibid. 
increase in the scope for weakening animal welfare standards. A chief concern includes the decrease in prosecutions for cases of cruelty, as the "statutory codes have until now been used to give magistrates guidance on where those being prosecuted have fallen short compared with good practice". ${ }^{132}$ Chief policy advisor at Compassion in World Farming, Peter Stevenson, illustrated his concerns by reference to the husbandry practices of pigs; claiming that "the government code on pigs is quite tough"133 as, for example, it stipulates that "tail docking should only be used as a last resort" ${ }^{134}$ he questions whether "the pig industry would keep such wording?" 135 concluding that "inevitably one will see a dilution of the codes" given that "the job of a government department is to hold the balance between competing interests" and not "to be subservient to the needs of industry" ${ }^{136}$ Fortunately, opposition to the proposed changes led Defra to abandon the move, and existing statutory codes were decidedly retained. ${ }^{137}$

I believe that lack of concern for animal welfare demonstrated by these three examples of past conservative policy provide sufficient reason to treat the pledges of ministers with caution, and to critique any further actions of transposition with the utmost scrutiny. This, combined with the first element of the difficulty of ensuring the transposition of EU animal law, help to further strengthen the premise of the third reason for the need to scrutinise the case for optimism, which is the following: that not only has there been clear intention in the past to avoid improving animal welfare protection in cases when it would be detrimental to business, but there is evidence to suggest that animal welfare interests will be subjugated in the Brexit process also. I will refer to three aspects of policy that substantiate this point; firstly, the UK's decision to ban the gold-plating of EU legislation; secondly, the suggestion of a compromise in prospective trade agreements; and thirdly, the indirect impact of a possible change in migration policy on animal welfare.

The heart of the problem when creating animal welfare legislation is, put bluntly by Defra, "those instances when animal welfare comes into conflict with other interests, such as economic pressures, development of improvements in human health or management of biodiversity". ${ }^{138}$ Indeed, as stated by the Prime Minister herself, the maintenance and improvement of standards will be prioritised only when "our industry is not put at a competitive disadvantage". ${ }^{139}$ The UK government made this exceptionally clear when in 2011 the coalition finalised its plan to end 'gold-plating' - "the process where a basic EU directive is given extra strength when being incorporated into UK law". ${ }^{140}$ The then Business Minister Michael Fallon announced that ministers were required to "transpose only the minimum necessary to comply with each directive", ${ }^{141}$ and expressed his intention to "block all legislative proposals" that failed to meet this criteria. ${ }^{142}$ According to former Business Secretary Vince Cable, this would mean implementing EU obligations in a way that would "foster, not hinder, UK growth by helping British businesses compete with their European neighbours", ${ }^{143}$ ensuring that British business remains "a powerhouse for economic growth

\footnotetext{
132 ibid.

133 ibid.

134 ibid.

135 ibid.

136 ibid.

${ }^{137}$ Mason, Rowena, “Ministers abandon plan to scrap farm animal welfare codes”, (The Guardian, $7^{\text {th }}$ April 2016), available at https://www.theguardian.com/environment/2016/apr/07/ministers-abandonplan-to-scrap-farm-animal-welfare-codes-chicken-farming, accessed 16 April 2018

${ }^{138}$ supra 1 , p5

${ }^{139}$ supra 1 , p8

${ }^{140}$ Davies, Chris, “Minister says UK 'gold plating' of EU laws has stopped”, (BBC, 24 April 2013), available at http://www.bbc.co.uk/news/uk-politics-22277927, accessed 16 April 2018

141 ibid.

142 ibid.

143 HM Government, “Government ends goldplating of European regulations”, (Department for 
and among the most competitive in the world". ${ }^{144}$ The impact of this was immediate; capitalising on this point, the then Conservative Chancellor of the Exchequer George Osborne used his Autumn statement to slam green policies, promising to make sure that "gold-plating of EU rules on things like habitats aren't placing ridiculous costs on British businesses" before planning a major expansion of the UK's road network "at irrevocable cost to the local environment". 145

Trading within the EU's single market has meant that, as all 28 Member States were required to implement baseline standards regarding production process and quality, animal welfare standards could not be lessened to below the baseline level to allow for competitive advantage. However, as it appears now that the UK will no longer be part of the single market, at least in the same way that it is now, it must turn to the rest of the world for future trade agreements. This, in itself, by no way means that standards of welfare will, in fact, be compromised in future trade agreements; indeed, there is reason to believe that "good animal welfare makes good business sense for the UK's future position in global markets" as increasingly consumers demand higher welfare products. ${ }^{146}$

It has not yet been possible for the UK to agree upon any trade deals; EU rules prohibit Member States from negotiating their own deals. ${ }^{147}$ However, as an exercise in speculation, the UK's recent trade deal negotiations with both Australia and the United States perfectly illustrate the difficulties that could be faced in negotiating with markets outside the EU. According to a report by The Times, Australia will "demand that Britain accepts hormonetreated beef as the price of a symbolic early Brexit trade deal". ${ }^{148}$ The prospective deal has been identified by Trade Secretary Liam Fox as "an early 'win'” for the effect it would have on reducing consumer costs, ${ }^{149}$ however it would entail a blow to animal welfare standards; the practice can increase animal weight gain by 10 per cent per day, and has been banned by the EU for reasons not limited to the fact that "at least one of the hormones used is carcinogenic". ${ }^{150}$ Fox also reopened "a cabinet rift over whether post-Brexit food standards should be lowered to facilitate a trade deal with the US", ${ }^{151}$ as the terms of US negotiators entailed reducing trade barriers to overlook the EU ban on the use of Ractopamine - a feed additive used in $28 \%$ of US pig farming that causes "death, lameness, stiffness, trembling and shortness of breath in farm animals" - in pork production. ${ }^{152}$ The terms of this deal could also require the UK to "accept imports of chlorine-washed chicken" - ${ }^{153}$ a common, yet "inhumane and unsanitary", process in the US that has been criticised for having no welfare

Business, Innovation and Skills, 15 December 2010), available at https:/www.gov.uk/government/news/government-ends-goldplating-of-european-regulations, accessed 16 April 2018

144 ibid.

${ }^{145}$ Harvey, Fiona, “Autumn statement: George Osborne slams ‘costly’ green policies”, (The Guardian, 29 November 2011), available at https:/www.theguardian.com/uk/2011/nov/29/autumn-statementgeorge-osborne-green-policies, accessed 16 April 2018

${ }^{146}$ supra 1 , p6

${ }^{147}$ Forsyth, Alex, "Reality Check: Does the UK trade with 'the rest of the world' on WTO rules?”, (BBC, $6^{\text {th }}$ November 2017), available at http://www.bbc.co.uk/news/uk-politics-41859691, accessed 16 April 2018

${ }^{148}$ Wright, Oliver, “Australia to demand Britain accepts hormone-treated beef”, (The Times, $2^{\text {nd }}$ April 2018), available at https://www.thetimes.co.uk/article/australia-to-demand-britain-acceptshormonetreated-beef-htwf9xxsb, accessed 16 April 2018

149 ibid.

150 ibid.

${ }^{151}$ Roberts, Dan, “Liam Fox reopens cabinet rift with defence of chlorinated chicken”, (The Guardian, $1^{\text {st }}$ November 2017), available at https://www.theguardian.com/politics/2017/nov/01/liam-fox-reopenscabinet-rift-with-defence-of-chlorinated-chicken, accessed 16 April 2018

152 supra 1 , p24

153 ibid. p24 
standards. ${ }^{154}$ Michael Gove has, on his part, provided assurances that there are "no circumstances under which chlorinated chicken would be allowed in the UK after Britain leaves the EU". ${ }^{155}$ Indeed, his staunch opposition may be sufficient to ensure that this remains the case. However if that is not the case, the effect of lowering our animal welfare trade standard policy would not only validate the lower standards of other nations, but it could also affect domestic welfare standards, as if the UK is unable to prevent the import of lower welfare products, "UK farmers are likely to oppose any strengthening of domestic farm animal welfare standards". 156

On a positive note, the pre-Brexit negotiation of trade deals provides reason to believe that the UK will not entirely end up risking the compromise of welfare standards under World Trade Organisation rules, ${ }^{157}$ which would ultimately be the case if specific trade deals were not negotiated beforehand. ${ }^{158}$ The outlook of the Minister of State responsible for Agriculture, Fisheries and Food is optimistic about this possible scenario; he does not believe "that anything along the lines that we would propose will cause any difficulty whatever with WTO rules". ${ }^{159}$ Additionally, there exists "legal authority to support the proposition that the UK could require imports of animal-derived food to meet welfare standards equivalent to its own, provided that there is no element of discrimination". ${ }^{160}$ However the risk lies with the fact that the improvements to animal welfare that have been identified as both desirable for the UK and possible after Brexit would likely need to be defended at the WTO, ${ }^{161}$ which could deter any attempts at improving welfare. Having said this, it is clear that the future trade negotiations, essential as they are to the survival of post-Brexit Britain, do in themselves pose a significant threat to not only the alleged improvements to be made to animal welfare standards, but standards that are currently guaranteed; negotiations require compromise, and on either animal welfare or cost to the consumer, the hammer must fall.

The negotiation of trade agreements on the global market will, therefore, pose a direct threat to animal welfare standards. Unfortunately, however, speculation also reveals other indirect but equally reproachable threats to animal welfare as a result of priority being given to other policy areas. Once again, this is an exercise in speculation, however an examination of the possible migration worker policy following Brexit provides clear reason to suggest that the change in migrant worker status may have adverse effects on certain aspects of animal welfare.

A 2017 Report produced by the House of Lords, entitled 'Brexit: Farm Animal Welfare', ${ }^{162}$ illustrates the crucial role played by veterinary staff in ensuring that farm animal welfare standards are upheld. According to Ms Ravetz, President of the British Veterinary Association (BVA), "Vets work with and support local farmers to meet standards, and Official Veterinarians, working in abattoirs in particular, play an essential role in maintaining

\footnotetext{
${ }^{154}$ Dawson, Simon, "Chlorine-washed chicken Q\&A: food safety expert explains why US poultry is banned in the EU”, (The Conversation, $2^{\text {nd }}$ August 2017), available at http://theconversation.com/chlorine-washed-chicken-qanda-food-safety-expert-explains-why-uspoultry-is-banned-in-the-eu-81921, accessed 16 April 2018

155 dan roberts

156 supra 1, p24

${ }^{157}$ supra 147

158 supra 1, p24

159 ibid p25

${ }^{160}$ See "Brexit: Getting the best deal for animals", (Wildlife and Countryside Link, and the UK Centre for Animal Law, January 2018), p24 for examination of caselaw

161 "What are the WTO rules that affect animal welfare?” (RSPCA Public Affairs Department), available at http://politicalanimal.org.uk/wp-content/uploads/2017/03/BrexitWTOtradebans.pdf, accessed 16 April 2018

${ }^{162}$ House of Lords, "Brexit: Farm Animal Welfare”, (European Union Committee, $5^{\text {th }}$ Report of Session 2017-19, 25 $5^{\text {th }}$ July 2017), p20
} 
animal health and welfare and making sure that animals are slaughtered humanely". ${ }^{163}$ The BVA, reflecting on likely changes in UK-EU trading relations, commented that following Brexit there could be "increased demand for veterinary certification and supervision, which would require more Official Veterinarians than are currently employed in the sector". ${ }^{164}$ This is based on the fact that "many countries require veterinary certification of food safety... before animal shipment", ${ }^{165}$ and the fact that "post-Brexit all EU countries are likely to be regarded as Third Countries for the purposes of exports and imports". ${ }^{166}$ With the need for increased competent workers, the situation becomes problematic because of the lack of surety of the position of migrant workers. According to Ms Ravetz, "over 90\% of our Official Veterinarians are non-UK EU 27 citizens", ${ }^{167}$ which is worrying because, as noted by the BVA, "without non-UK EU vets, there may not be enough appropriately qualified vets to meet workforce needs which would have a significant effect on animal health and welfare, public health and trade" ${ }^{168}$ The BVA accordingly concluded its contribution by emphasising that the "Government must ensure that agriculture has access to the migrant workers it is so reliant on”. 169

\section{Part Three: Beyond the Façade}

With the three reasons now having been set out and supported by clear and credible evidence, I have constructed a compelling case has for the need to be sceptical when scrutinising future policymaking that could in any way affect animal welfare. With an undeniably poor record of consideration for animal welfare, including in the recent Withdrawal Bill proposal, why, then, have Prime Minister Theresa May and Defra Secretary Michael Gove been so far reaching in setting out the future of animal welfare policy? Stepping back from the topic of animal welfare and recognising its place within the greater policy and procedure of the Brexit can offer some insight into this. By analysing these animal welfare pledges from this enlightening perspective, I offer two possible, and I believe probable, explanations for such ambitious promises.

My first suspicion is that the promises to improve animal welfare after Brexit are an appeal to populism in an attempt to find common ground in a country with a clear and considerate political divide. The referendum result on Brexit is, in itself, irrefutable evidence of this division $-48 \%$ of votes to remain in the EU, and $52 \%$ of votes to leave. ${ }^{170}$ Of course, this is not a perfect reflection of national sentiments, as only $72.2 \%$ of registered voters turned out, ${ }^{171}$ and more significantly the multitude of reasons for voting either way means that certain issues will have a greater unity of support than others. The division is not limited to the demos, but is blatant and bitter between the political parties and even between the leadership of each party, failing to agree on such fundamental and crucial decisions as whether to pursue a hard or soft Brexit.

However it is clear that animal welfare concerns, by their emotive nature and ability to capture the hearts of pet lovers, provide a good means for uniting the public against a common enemy - cruelty to animals. For it was only as a result of the public pressure that two of the most recent animal welfare improvements have been carried out; the increase in

\footnotetext{
163 ibid, p20

164 ibid, p20

165 ibid, p20

166 ibid, p20

167 ibid. p20

168 ibid. p20

169 ibid. p20
}

170 "EU Referendum Results", (The Electoral Commission) available at https://www.electoralcommission.org.uk/find-information-by-subject/elections-and-referendums/pastelections-and-referendums/eu-referendum/electorate-and-count-information, accessed 16 April 2018 171 ibid. 
sentencing for abhorrent crimes, which was drawn to the attention of policy-makers by public outrage, and the inclusion of sentience in the Draft Withdrawal Bill following its omission.

If this is an appeal to populism, and is, in fact, an attempt to weaken the national divide by unity on common ground, this would be welcome, and should be encouraged; not only would this be beneficial for domestic politics, but, ultimately, it would be of great advantage to animal welfare developments also. However if this were the case, my primary concern would be that motivation would fade away as quickly as it came, and the promises that captured the support and sentiment of the nation would not be followed through.

My second suspicion is that the ambitiousness of the promises, as part of the plan to "deliver for the British people by making a 'success of Brexit", ${ }^{172}$ is an attempt to portray the Brexit as exactly that - a success. The Brexit, when situated in the wider political context, could be argued to be just one element of "a political counter-revolution against the European Union", ${ }^{173}$ perhaps only "the first of many tremors leading up to a larger political earthquake that will be felt all over the European continent". ${ }^{174}$ Boris Johnson - former Conservative Mayor of London, current foreign secretary and lead proponent of the Leave campaign famously announced that Britain will make a "titanic success of Brexit" 175 by "taking the machete of freedom to the brambles of EU legislation"176 and "creating something immensely positive", ${ }^{177}$ claiming it to be "what people of this great continent want to achieve". ${ }^{178}$ Theresa May, when speaking about negotiating a new relationship with the EU after Brexit, expressed herself as "confident we can set an example to the world". However given the clear difficulties that become evermore visible, it is perhaps more realistic to believe that the Brexit government is not so much setting an example, as selling a vision of success that, as I have proved, may be unlikely to succeed. While this paper is not the place to speculate too extensively on this, acknowledgement of this possibility, in terms of the UK and its certain aspects of its attitude displayed during the campaign, does, I believe, have implications for the possibility of animal welfare being taken seriously.

Political rhetoric has played an enormous role in the Brexit process so far; the campaign has been branded "one of the most divisive, ugly and corrosive campaigns in modern British history". ${ }^{179}$ Highly emotive, it saw reason and rationality in the form of academic expertise side-lined by fear and concern for sovereignty, power and control. It is not merely on the topic of animal welfare that rhetoric has been used to portray the Brexit as a success; the public has, in fact, been misled in terms of many fundamental elements of the Brexit. Two key examples present themselves; firstly, in discussing financial cost of leaving the EU, Theresa May stated that "Britain had no legal obligation to cover financial liabilities accrued by the bloc", ${ }^{180}$ to which Boris Johnson brashly added, to the joy of the Leave supporters,

172 “Theresa May says UK can 'set example to world’ in Brexit deal”, (BBC, $5^{\text {th }}$ March 2018), available at http://www.bbc.com/news/uk-politics-43288043, accessed 16 April 2018

${ }^{173}$ Leonard, Mark, "Europe seen from the outside - the British view”, (European Council on Foreign Relations, $\quad 4^{\text {th }} \quad$ August 2016), available at http://www.ecfr.eu/article/commentary_europe_seen_from_the_outside_the_british_view_7091, accessed 16 April 2018

174 ibid.

${ }^{175}$ Elgot, Jessica, “Brexit will be titanic success, says Boris Johnson”, (The Guardian, $3^{\text {rd }}$ November 2016), available at https://www.theguardian.com/politics/2016/nov/03/brexit-will-be-titanic-successsays-boris-johnson, accessed 16 April 2018

176 ibid.

177 ibid.

178 ibid.

${ }^{179}$ Parry, Dr. Katy, “The toxicity of discourse: reflections on UK political culture following the EU Referendum”, (EU Referendum Analysis 2016), available at http://www.referendumanalysis.eu/eureferendum-analysis-2016/section-5-campaign-and-political-communication/the-toxicity-of-discoursereflections-on-uk-political-culture-following-the-eu-referendum/, accessed 16 April 2018

${ }^{180}$ Acton, Michael, "Brexit rhetoric bumps into reality”, (Financial Times, $1^{\text {st }}$ December 2017), available at https://www.ft.com/content/9e5113c0-d681-11e7-8c9a-d9c0a5c8d5c9, accessed 16 April 2018 
that European Union members could "go whistle". ${ }^{181}$ However mere months later, UK negotiators conceded, admitting "Britain would be ready to honour its share of all the financial commitments identified by the bloc". ${ }^{182}$ The second example is the initial controversy that surrounded the question of a transition period; Brexit negotiator David Davis initially dismissed the idea of any transitional deal as "not what we're after", but it has since been accepted that such a period is necessary. ${ }^{183}$ More than merely necessary, it appears that the transitional period is essential, given the aforementioned difficulties that a transition period would reduce.

The problem with this optimism manifested in misleading rhetoric is that, if this were the case, as there is reason to believe, the problem lies far deeper than the question of maintaining animal welfare standards; a campaign constructed upon lies that deceives the public is a threat to democracy which, ironically, is something that prominent Leave campaigners criticised the EU for lacking. ${ }^{184}$

\section{Conclusion}

Both before and after the decision of the UK to leave the EU, the lead proponents of the Brexit have presented themselves as setting "an example to the world". ${ }^{185}$ As subjects of policy debate and negotiation, animals across all ambit of British society and industry have been promised the guarantee of, and in some cases improvement on, current welfare standards enjoyed as benefactors of European animal law. With a positive track record of animal law development, and plenty of room for improvement when free from the shackles of European Union principles of free movement, a vision of success has been portrayed. However, by reference to recent Conservative animal welfare policies, the current negotiations and possible agreements, and the difficulties inherent in the transposition of the Acquis Communautaire, framed within the greater political context of the Brexit, I have presented a compelling case for the possibility that the promises of improvement must be met with caution; it is my believe, at least that the ambition and optimism by leading ministers is a product of political rhetoric and an appeal to populism. The Brexit may well become the opportunity for the much-anticipated political reinvigoration of animal welfare concerns. If this is, indeed, the case, I feel that it could only be achieved as a result of the continued and augmented role played by both the public and animal protection organisations to hold the government accountable with outrage and uproar; a common element that, as I have demonstrated, has been key to both the prevention of Conservative policies that would have been detrimental to animal welfare, and the impetus behind the development of the positive ones. It is in essence of this, therefore, that in presenting this examination of the implications of the Brexit on animal welfare in the UK in such a way, I hope to have instilled in the reader a sense of duty to scrutinise rhetoric with rigour, to replace support for unearned optimism with critical scepticism, and to demand the fulfilment of these promises, no matter how ambitiously they are presented nor how uncharacteristic they may seem.

\section{Bibliography}

\section{Legislation}

\section{Animal Welfare (Sentencing and Recognition of Sentience) Draft Bill 2017}

\footnotetext{
181 ibid.

182 ibid.

183 ibid. reality-check, accessed 16 April 2016

${ }^{185}$ supra 172
}

${ }^{184}$ Leading leave campaigners have described the EU as "a dysfunctional beaurocracy that has no proper democratic oversight”, see Rankin, Jennifer, “Is the EU undemocratic?” (The Guardian, 13 ${ }^{\text {th }}$ June 2016), available at https:/www.theguardian.com/world/2016/jun/13/is-the-eu-undemocratic-referendum- 
2. Draft Wild Animals in Circuses Bill 2010

3. Hunting Act 2004

4. Martin’s Act 1822

\section{Official Publications}

1. HM Government Policy Paper, "Draft Animal Welfare (Sentencing and Recognition of Sentience) Bill 2017”, (Department for Environment, Food and Rural Affairs, 12 December 2017) available at https://www.gov.uk/government/publications/draftanimal-welfare-sentencing-and-recognition-of-sentience-bill-2017, accessed 16 April $\underline{2018}$

2.HM Government Pre-Legislative Scrutiny of the draft Animal Welfare (Sentencing and Recognition of Sentience) Bill 2017, available at https://publications.parliament.uk/pa/cm201719/cmselect/cmenvfru/709/70902.htm accessed 16 April 2018

3.HM Government Written statement by Secretary of State Michael Gove, "Animal Welfare”, (23 November 2018) available at https://www.parliament.uk/business/publications/written-questions-answersstatements/written-statement/Commons/2017-11-23/HCWS267/, accessed 16 April 2018

4.HM Government, “Government ends goldplating of European regulations”, (Department for Business, Innovation and Skills, 15 December 2010), available at https://www.gov.uk/government/news/government-ends-goldplating-of-europeanregulations, accessed 16 April 2018

5. HM Government, Wild Animals In Circuses (Draft), April 2013, Briefing Paper, p8

6. House of Lords, "Brexit: Farm Animal Welfare”, (European Union Committee, $5^{\text {th }}$ Report of Session 2017-19, 25 th $^{\text {t }}$ July 2017), p20

7. Policy Paper, “Legislating for the United Kingdom's withdrawal from the European Union”, (Department for Exiting the European Union, 15 ${ }^{\text {th }}$ May 2017), available at https://www.gov.uk/government/publications/the-repeal-bill-white-paper/legislatingfor-the-united-kingdoms-withdrawal-from-the-european-union, accessed 16 April 2018

Speeches

1.Secretary of State Michael Gove, “Farming for the Next Generation” (5 January 2018) available at https://www.gov.uk/government/speeches/farming-for-the-nextgeneration, accessed 16 April 2018

2. Secretary of State Michael Gove, "The Unfrozen Moment - Delivering a Green Brexit”, (21 July, 2017) available at https://www.gov.uk/government/speeches/theunfrozen-moment-delivering-a-green-brexit, accessed 16 April 2018

Reports

1. "Brexit: Getting the best deal for animals”, (Wildlife and Countryside Link, and the UK Centre for Animal Law, January 2018)

Online Articles

1. “Animal Welfare: Theresa May Promises to Improve Standards”, (BBC, 22 November 2017) available at http://www.bbc.co.uk/news/uk-politics-42083552, accessed 16 April 2018 
2. “EU Withdrawal Bill: A guide to the Brexit repeal legislation”, (BBC, 13 November 2017), available at http://www.bbc.co.uk/news/uk-politics-39266723, accessed 16 April 2018

3. "Forty animal charities call for Government to put words into action on Post-Brexit animal welfare”, (Wildlife and Countryside Link, 16 January 2018), available at https://www.wcl.org.uk/forty-animal-charities-call-for-government-to-put-wordsinto-action-on-post-brexit-animal-welfare.asp, accessed 16 April 2018

4. "Strengthen the Hunting Act”, (League Against Cruel Sports), available at https://www.league.org.uk/hunting-act, accessed 16 April 2018

5. “Theresa May says UK can 'set example to world' in Brexit deal”, (BBC, $5^{\text {th }}$ March 2018), available at http://www.bbc.com/news/uk-politics-43288043, accessed 16 April 2018

6."What are the WTO rules that affect animal welfare?", (RSPCA Public Affairs Department), available at http://politicalanimal.org.uk/wpcontent/uploads/2017/03/BrexitWTOtradebans.pdf, accessed 16 April 2018

7.Acton, Michael, "Brexit rhetoric bumps into reality", (Financial Times, $1^{\text {st }}$ December 2017), available at https://www.ft.com/content/9e5113c0-d681-11e7-8c9ad9c0a5c8d5c9, accessed 16 April 2018

8. Becket, Adam, "Brexit poses a threat to animal welfare in the UK, a new report warns", (Business Insider, 25 July 2017), available at http://uk.businessinsider.com/brexitthreatens-the-uk-high-animal-welfare-standards-2017-7, accessed 16 April 2016

9.Becket, Adam, "Theresa May insisted on including fox hunting pledge in Conservative manifesto", (Business Insider, 27 Nov 2017), available at http://uk.businessinsider.com/theresa-may-insisted-on-including-fox-hunting-pledgein-conservative-manifesto-2017-11, accessed 16 April 2018

10. Case, Philip, "PM makes Brexit pledge on animal welfare”, (Farmers Weekly, 15 March 2017), available at http://www.fwi.co.uk/news/pm-makes-brexit-pledge-onanimal-welfare.htm, accessed 16 April 2018

11. Davies, Chris, "Minister says UK 'gold plating' of EU laws has stopped”, (BBC, 24 April 2013), available at http://www.bbc.co.uk/news/uk-politics-22277927, accessed 16 April 2018

12. Dawson, Simon, "Chlorine-washed chicken Q\&A: food safety expert explains why US poultry is banned in the EU”, (The Conversation, $2^{\text {nd }}$ August 2017), available at http://theconversation.com/chlorine-washed-chicken-qanda-food-safety-expertexplains-why-us-poultry-is-banned-in-the-eu-81921, accessed 16 April 2018

13. Elgot, Jessica, "Brexit will be titanic success, says Boris Johnson”, (The Guardian, $3^{\text {rd }} \quad$ November 2016), available at https://www.theguardian.com/politics/2016/nov/03/brexit-will-be-titanic-successsays-boris-johnson, accessed 16 April 2018

14. Forsyth, Alex, "Reality Check: Does the UK trade with 'the rest of the world' on WTO rules?”, (BBC, $6^{\text {th }}$ November 2017), available at http://www.bbc.co.uk/news/ukpolitics-41859691, accessed 16 April 2018

15. Harvey, Fiona, “Autumn statement: George Osborne slams ‘costly’ green policies”, (The Guardian, 29 November 2011), available at https://www.theguardian.com/uk/2011/nov/29/autumn-statement-george-osbornegreen-policies, accessed 16 April 2018

16. Hunt, Alex, and Wheeler, Brian, "Brexit: All you need to know about the UK leaving the EU”, (BBC, 12 April 2018), available at http://www.bbc.co.uk/news/uk-politics32810887 accessed 16 April 2018

17. Leonard, Mark, "Europe seen from the outside - the British view", (European Council on Foreign Relations, $4^{\text {th }}$ August 2016), available at http://www.ecfr.eu/article/commentary_europe_seen_from_the_outside_the_british_ view_7091, accessed 16 April 2018 
18. Mason, Rowena, “Gove says UK will specifically recognise animal sentience”, (The Guardian, 23 November 2017), available at https://www.theguardian.com/world/2017/nov/23/uk-law-will-specifically-recogniseanimal-sentience-michael-gove, accessed 16 April 2018

19. Mason, Rowena, “Government Planning to Repeal Animal Welfare Codes” (The Guardian, 25 March 2016) available at https://www.theguardian.com/lifeandstyle/2016/mar/25/government-planning-torepeal-animal-welfare-codes, accessed 16 April 2018

20. Mason, Rowena, "Ministers abandon plan to scrap farm animal welfare codes", (The Guardian, $\quad 7^{\text {th }} \quad$ April 2016), available at https://www.theguardian.com/environment/2016/apr/07/ministers-abandon-plan-toscrap-farm-animal-welfare-codes-chicken-farming, accessed 16 April 2018

21. Mason, Rowena. "Government shelves foxhunting vote after SNP opposition", (The Guardian, $\quad 14$ July 2015) https://www.theguardian.com/uknews/2015/jul/14/foxhunting-vote-shelved-by-tories-in-face-of-snp-opposition accessed 16 April 2016

22. Montague, Brendan, “Animal charities call on Theresa May’s government to 'put words into action' on post-Brexit animal welfare”, (The Ecologist, 17 January 2018), available at https://theecologist.org/2018/jan/17/animal-charities-call-theresa-maysgovernment-put-words-action-post-brexit-animal, accessed 16 April 2018

23. Osbourne, Samuel. “Teresa May announces she wants to bring back fox hunting”, (The Independent, 9 May 2017) http://www.independent.co.uk/news/uk/politics/theresa-may-fox-hunting-bring-backban-repealconservative- tories-general-election-rural-vote-a7726506.html accessed 16 April 2018

24. Parry, Dr. Katy, "The toxicity of discourse: reflections on UK political culture following the EU Referendum”, (EU Referendum Analysis 2016), available at http://www.referendumanalysis.eu/eu-referendum-analysis-2016/section-5-campaignand-political-communication/the-toxicity-of-discourse-reflections-on-uk-politicalculture-following-the-eu-referendum/, accessed 16 April 2018

25. Rankin, Jennifer, "Is the EU undemocratic?" (The Guardian, 13 ${ }^{\text {th }}$ June 2016), available at https://www.theguardian.com/world/2016/jun/13/is-the-eu-undemocraticreferendum-reality-check, accessed 16 April 2016

26. Roberts, Dan, "Liam Fox reopens cabinet rift with defence of chlorinated chicken”, (The Guardian, $1^{\text {st }} \quad$ November 2017), available at https://www.theguardian.com/politics/2017/nov/01/liam-fox-reopens-cabinet-riftwith-defence-of-chlorinated-chicken, accessed 16 April 2018

27. Stone, Jon, "Theresa May says she supports fox hunting because other ways of killing foxes are 'cruel'”, (The Independent, 16 May 2017), available at https://www.independent.co.uk/news/uk/politics/theresa-may-fox-huntingconservatives-tories-ban-bring-back-repeal-hunting-act-general-election-2017a7737881.html, accessed 16 April 2018

28. Stone, Jon. "David Cameron says he wants to repeal the fox hunting bill”, (The Independent, 6 March 2015) http://www.independent.co.uk/news/uk/politics/davidcameron-says-he-wants-to-repeal-the-fox-hunting-ban-10091571.html accessed 16 April 2018

29. Wright, Oliver, “Australia to demand Britain accepts hormone-treated beef”, (The Times, $2^{\text {nd }}$ April 2018), available at https://www.thetimes.co.uk/article/australia-todemand-britain-accepts-hormonetreated-beef-htwf9xxsb, accessed 16 April 2018 